DOI https://doi.org/10.18551/rjoas.2017-11.18

\title{
ROAD DATA AND INFORMATION PROVISION IN SUPPORTING THE IMPLEMENTATION OF JAKARTA SMART CITY PROGRAM: STUDY AT HIGHWAYS DEPARTMENT OF JAKARTA
}

\author{
Purwanti Eni*, Suryadi, Setyowati Endah \\ Master's Degree Program in Public Administration, Faculty of Administrative Science, \\ University of Brawijaya, Indonesia \\ *E-mail: purwanti.eni@gmail.com
}

\begin{abstract}
Information is a valuable material in today's digital era. Many organizations have considered data as an important asset which is then managed to be information thoroughly. This trend has influenced government organizations as well which begin to realize the importance of data and information in the information era. Indonesian government is actively campaigning for a single data movement for development with a more responsible, effective and efficient development objective. Provincial Government of DKI Jakarta through Jakarta Smart City (JSC) Program also implements single development data movement to encourage public information disclosure and public service innovation. Through Open Data program (https://data.jakarta.go.id), all government agencies of DKI Jakarta or related provinces are expected to actively participate in managing the data and information well and making them public. This also applies to Highways Department of DKI Jakarta. However, this department encounters several constraints on its participation in Open Data JSC. The findings of this study found that the management of road data and information in Highways Department of DKI Jakarta was done in a conventional manner and the scope was not yet comprehensive to the mandatory activities of data and road information management in accordance with the laws and regulations. Road data and information cannot support the implementation of the JSC Program due to the inability of Highways Department of DKI Jakarta to provide complete, accurate, up-to-date, easily obtained, open and accessible data and information both for the administrators and the public. There are four factors causing the problem, namely: too many rules (overregulation), no implementation guidelines, no separate data unit, and no optimal utilization of information and communication technology (ICT). While the supporting factors are: having a command center, having complaints channels, and the portal open data as data storage. Overcoming the four inhibiting factors was expected to achieve the data and information path in accordance with the legislation criteria and able to support the implementation of Jakarta Smart City (JSC) Program.
\end{abstract}

\section{KEY WORDS}

Policy analysis, road data, information, open data, Patton-Sawicki, smart city.

The development of information technology has spurred new ways of living (Wardiana, 2002: 1). Since the opening of internet access to the public, information technology enters a new era and spreads fast. It is not surprising if nowadays we tend to do "all-online way" in meeting everyday life needs. Supported with smartphone technology, "all-online way" grows and expands rapidly. The government obviously wants to respond to people aspirations with "online" paradigm. Therefore, the concept of e-government begins for access and products of government services to the public. Starting from the use of e-government applications, such as e-procurement, e-budgeting, e-performance etc., the concept of smart city emerges.

Muliarto (2015) states that smart city is the concept of urban planning by utilizing technological developments that will make easier and healthier life with high levels of efficiency and effectiveness. The realization of the smart city concept depends on the potential and policy directions of each region. Falconer and Mitchell (2002: 2) reveal urban or community conditions have the potential to implement smart city as a solution for the following problems: (1) increased population, currently more than $50 \%$ of the world's 
population lives in urban areas. This creates a complicated problem in urban infrastructure (transportation, housing, clean water, electricity, and services). Many of them are in need of redesign and large capital expenditures; (2) polarized economic growth in urban areas. Major cities around the world will contribute $65 \%$ to gross domestic product (GDP) from 2010 to 2025; (3) increased greenhouse gas emissions. Urban areas face the challenges of sustainable living strategies including transportation, water resources management, urban planning, and environment-friendly buildings; (4) reduced financial budget. The urban economic climate tends to place tight budgetary constraints, thus reducing the ability to respond to pressures.

Jakarta Smart City (JSC) concept is implicitly stated in Regional Legislation No.2 of 2013 on Jakarta Medium Term Development Plan (RPJMD) 2013-2017 in the vision and mission of the elected governor-deputy governor for that period. The vision of Jakarta's development in that period is New Jakarta, a neatly organized modern city, a decent and humane dwelling place, a cultivated society, and is supported with a public-oriented government service. Implementation of smart city in Jakarta is supported by several things, among others: high and fast-paced economic activity, large population and high population growth rate, uneven infrastructures compared to population growth, tourism and education activities, and Jakarta as the center of Indonesian state government. All these things lead to all problems considered normal in other areas become very complex problems in Jakarta. In 2015 , the population growth rate of Jakarta is $1.09 \%$ with a population of about 10 million people and the land area of about $633 \mathrm{~km}^{2}$, making Jakarta as the most populous province in Indonesia.

Jakarta Smart City Management Unit as the manager of JSC Program makes smart city concept based on 6 (six) pillars: Smart Governance, Smart People, Smart Living, Smart Mobility, Smart Economy, and Smart Environment. Through smart city, data and information are expected to be presented more transparently to increase citizen participation in development making Jakarta becomes a smart city because it involves the citizens, the government, the power, the money, and the space to make a better life for all people (http: //smartcity.jakarta.go.id).

One of the subsystems which build JSC is an integrated data portal which provides data from all units and work units in Provincial Government of DKI Jakarta (https://data.jakarta.go.id). Data portal is built based on Governor Regulation No. 181 of 2014 on System and Procedure of Development Data and Information Management. It is expected to be an accurate, up-to-date, open, integrated, complete, accountable, dynamic, reliable, valid, accessible and sustainable integrated data portal with the intention of delivering quality development planning, providing effective development control, and enhancing community participation.

One of the data source organizations is the Highways Department. According to Governor Regulation No. 273 of 2016 on the Organization and Working Procedures of Highways Department, the main task of this department is to carry out planning, development, maintenance, evaluation and security of roads and bridges along with complementary buildings and road equipment. However, in implementing the physical activity, Highways Department always faces several problems every year due to lack of information when planning stage, such as the roads have been heavily damaged and have not been repaired for years.

Based on this fact, it can be concluded that road data and information in Highways Department cannot meet the criteria set out in Governor Regulation No. 181 of 2014. The problem of road data and information not only disturbs internal planning function, but also hinders the performance of JSC program. Whereas the Instruction of the Governor of DKI Jakarta Province No. 223 of 2015 on the Use of JSC Application in the Provincial Government of DKI Jakarta requires active participation of all SKPD/UKPD (Regional Work Unit, Satuan Kerja Perangkat Daerah/Unit Kerja Perangkat Daerah) in utilizing JSC application or subsystem. Therefore, the provision of data and road information into https://data.jakarta.go.id portal is a necessity. 
Obviously, the merger cannot be done immediately, especially when the technology bases of the two systems are not the same. JSC program is an ICT-based system, while the data and information supply system is still conventional. Many issues must be considered, prepared, or fulfilled before the merger begins. A clear description of the provision of road data and information at Highways Department and Smart City Programs will lead to the constraining and supporting factors of the merger. Policy analysis provides the best alternative and recommendation that aims to overcome the inhibiting factors to solve the problem. The analysis is done using Patton-Sawicki's version of policy analysis theory, since this theory is considered to be sufficiently structured to perform the analytical stages and is designed to conduct a rapid policy analysis while still adhering to the principle of providing sound and appropriate recommendations.

\section{LITERATURE REVIEW}

Patton \& Sawicki argues that policy analysis can be done before and after the policy. Post-policy policy analysis is usually descriptive and is usually called ex-post (Michael Carley's term), post-hoc (Lineberry's term), and retrospective (William Dunn's term) analysis. Policy analysis conducted before the policy is called ex-ante (Carley's term), pre-hoc (Lineberry's term), anticipatory (Teitz's term), and prospective (William Dunn's term) analysis. This method of analysis is divided into two, namely predictive and prescriptive analysis. Predictive analysis refers to projected future conditions as a result of policy adoption. Prescription analysis refers to policy recommendations. Policy recommendations which are general and do not provide a particular focus are called advices. Whereas, the recommendation that presses policy makers into choosing a policy is called persuasive advice.

Based on existing models of policy analysis and the views on a quickly-applied but good-impact analysis method, Patton \& Sawicki develop an analytical model called A Basic Policy Analysis process. This model consists of six policy analysis steps outlined in Figure 1 which presents policy analysis model of Patton \& Sawicki.

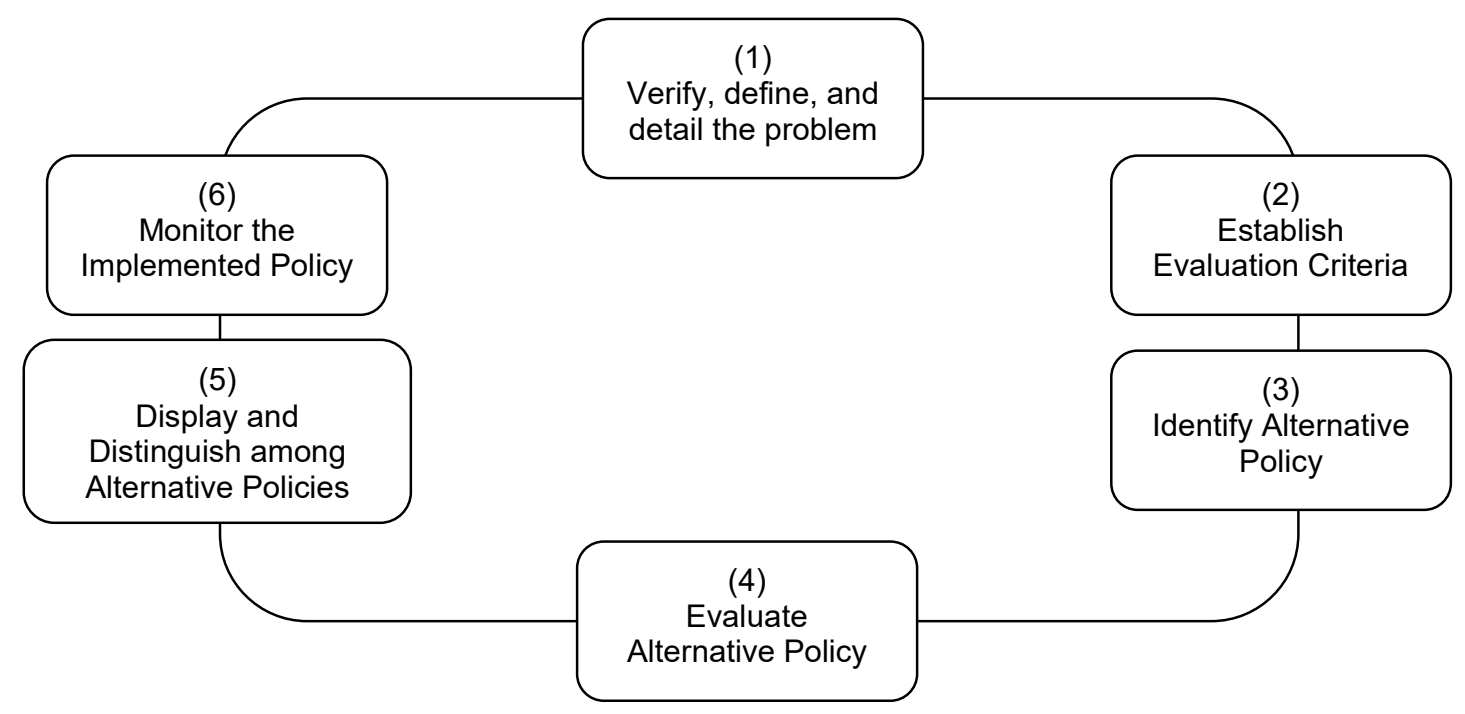

Figure 1 - Policy Analysis Model of Patton \& Sawicki

Source: Public Policy Fifth Edition, Riant Nugroho (2014: 313)

(1) Verify, define, and detail the policy problems:

This step is often very difficult because of unclear client's goals or conflictual objectives to be achieved. There are two methods of approach which are widely used in addition to other methods. The first method is the pragmatic approach which is used when many contraries are encountered between policy alternatives so consideration is given to the 
lowest cost alternative. The second method is the social-criterion approach in which the policy analyst must find the hidden meaning or expression of the social problem to be solved.

(2) Establish the policy criteria:

Criteria are specific statements about the target dimensions to be used in policy evaluation. It is necessary to distinguish some concepts to understand the criteria. Goals are statements declared formally and broadly about what will be achieved in the future. Objectives are more concrete statements and focus on the goals to be achieved, usually target time and target population are also determined. Measures are the operational, visible, and often stated criteria of definitions quantitatively.

(3) Identify alternative policies:

This step is done by looking for alternatives which can be used to solve the problem. So, it is important to recognize the hidden meaning or expression of social problems to be solved. Policy analyst should identify the root of the problem to think about and determine the right and rational alternatives.

(4) Evaluate alternative policies:

The phases stated by Patton \& Sawicki are specific to the policy to be taken (ex-ante evaluation). They introduce two methods of forecasting and evaluation. Forecasting analysis includes extrapolation, modeling, and intuitive forecasting. Extrapolation techniques are to make future projections using current data and trends. Theoretical modeling technique is a forecasting technique using a particular theory approach.

(5) Display and distinguish among policy alternatives:

Patton \& Sawicki assert that the policy analysis process is an evaluation of policy alternatives from the technical, economical, and political aspects, linked to their implementation. However, displaying a policy alternative faces some challenges, such as the conflict between individual rationality and group rationality; and the problem of multiple criteria. In policy analysis, one must find conflicts between the problem-solving aims and the above criteria by (1) a simple comparison approach, (2) a score-card matrix, and (3) another matrix.

(6) Monitor the implemented policy:

This phase aims to monitor the extent to which the suggested policy alternatives solve the problem. In the case of ex-ante policy analysis, one can use forecasting method or scenario writing.

\section{METHODS OF RESEARCH}

This research used qualitative research method with descriptive approach.

The research focused on: (1) production, update, and delivery of road data and information by Highways Department of DKI Jakarta; (2) inhibiting and supporting factors affecting road data and information in accordance with smart city criteria; and (3) analysis of combining provision of road data and information into JSC Program using policy analysis model of Patton \& Sawicki. This research was located in Jakarta, at Highways Department of DKI Jakarta and Jakarta Smart City Management Unit under Department of Communications, Informatics, and External Relations.

\section{RESULTS AND DISCUSSION}

Results. The legal basis for the provision of road data and information used at Highways Department of DKI Jakarta is all Indonesian laws relating to roads concerning road data and information. Table 1 presents these legal bases.

Principles of laws and regulations provisions in Table 1 are summarized as follows:

1. The government, both central and regional, plays a vital role in the implementation of road data and information.

2. The government is obliged to fulfill complete, accurate, up-to-date, easily obtained, open and accessible road data and information for the administrators and the public. 
3. In carrying out road data and information, Government and regional government are obliged to fulfill road databases in accordance with the laws and regulations provisions. They are obliged to complete other road information in accordance with laws and regulations provisions as well, such as road network plan and information on construction services activities.

4. Road data and information as a subsystem is a part of other larger systems, such as information and communication system of integrated traffic and road transportation as well as spatial and regional plan system.

5. Road databases are used to know the state, agency or individual assets toward roads. They are also used as source of information for the plans preparation purposes and roads implementation programs, as well as to perform other roads implementation functions.

6. The management of road data and information specified in existing laws and regulations is a conventional-based system. That is, road data and information are handled and made with hard copies. The creation and storage has not involved internet-based technology.

Table 1 - Legal Bases of Road Data and Information Provision in Jakarta

\begin{tabular}{|c|c|c|}
\hline No & Legislation & Articles \\
\hline 1 & Law No. 38 of 2004 on Roads & $14,15,16$, and 62 paragraph 1 letter $d$. \\
\hline 2 & $\begin{array}{l}\text { Law No. } 22 \text { of } 2009 \text { on Traffic and Road } \\
\text { Transportation }\end{array}$ & $\begin{array}{l}7 \text { paragraph 1, } 7 \text { paragraph 2, } 7 \text { paragraph } 2 \text { letter a, 8, } 245 \\
\text { paragraph 1, } 245 \text { paragraph 2, } 245 \text { paragraph } 3,246,247, \\
\text { and } 250 .\end{array}$ \\
\hline 3 & $\begin{array}{l}\text { Law No. } 26 \text { Year } 2007 \text { on Spatial } \\
\text { Management }\end{array}$ & $\begin{array}{l}7 \text { paragraph } 1,7 \text { paragraph } 2,8,9,10,11 \text {, and the } \\
\text { elucidation of article } 15 \text {, paragraph } 2 .\end{array}$ \\
\hline 4 & Law No. 2 of 2017 on Construction & $\begin{array}{l}4 \text { paragraph } 1 \text { letter } \mathrm{g}, 5 \text { paragraph } 1 \text { letter } \mathrm{m}, 5 \text { paragraph } \\
8,6 \text { paragraph } 7,6 \text { paragraph } 7 \text { letter } \mathrm{b} \text {, and } 8 \text { letter } \mathrm{b} \text {. }\end{array}$ \\
\hline 5 & $\begin{array}{l}\text { Government Regulation No. } 34 \text { of } 2006 \text { on } \\
\text { Roads }\end{array}$ & $114-117$. \\
\hline 6 & $\begin{array}{l}\text { Regulation of the Minister of Public Works } \\
\text { No. } 78 \text { / PRT / M / } 2005 \text { on Road Databases }\end{array}$ & $\begin{array}{l}2,3,5,6,7,8,9, \text { paragraph } 1-3,10, \text { paragraph } 1-5,11,12 \text {, } \\
13, \text { and } 15, \text { paragraph } 1-7 \text {. }\end{array}$ \\
\hline
\end{tabular}

The mechanism of data acquisition and road information in Highways Department of DKI Jakarta Province explained by Mr. Af and Mr. HP as technical planning section staff in interview session can be summarized in the following stages:

Data collection. There are 4 (four) categories of road data, namely road damage data, road condition data, road trace data, and complementary building data. There are 4 (four) sources of data, namely Highways Department of DKI Jakarta Provincial, third parties or consultants, other agencies, and citizens and communities. Data collection is done through 4 (four) techniques, namely: field survey, request of information from other institution, direct aspirations from citizens or through Musrenbang (Development Planning Deliberation, Musyawarah Rencana Pembangunan), and citizens complaints through complaints channels. This stage generates a sketch of the location, the dimensions of the road as well as the completeness, and photographs which support the description of the situation and conditions in the field.

Data processing. Data processing is done by processing the results of data collection. This stage generates recapitulation and field sketches using auto cad. Once processed, these data become useful information such as information on the volume of road damage.

Data and information archiving, presentation, and dissemination. Street information is stored in hard copy and soft copy (word or excel). It is bundled in a large map that has been named to facilitate searching when needed again. Presentation of road data and information are through exposures during official meetings or coordination meetings. The dissemination of information is through official letters and email.

Data and information update. Data update is done by the official of Highways Department on the files or databases they have in the computer (soft copy) or hard copy by entering the results of related year activity in those files. 
Figure 2 and 3 show the process of providing road data and information in Highways Department of DKI Jakarta.

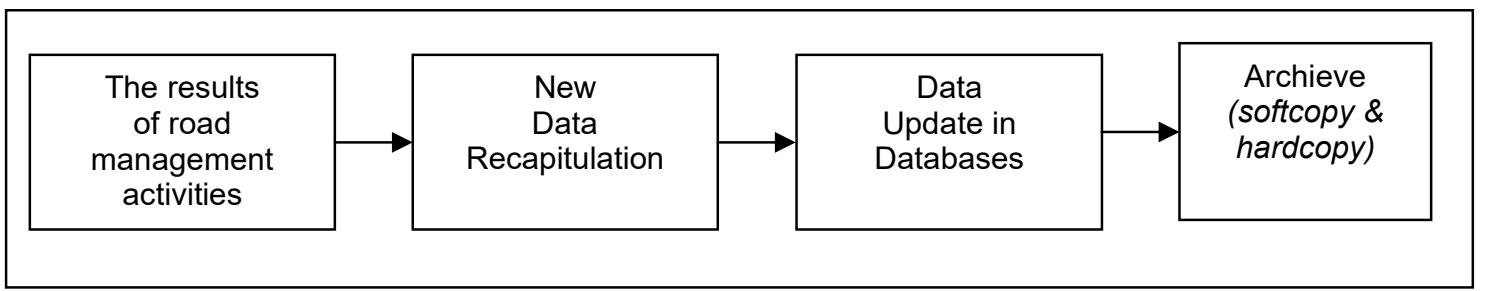

Figure 2 - Road Data and Information Mechanism Updates in Highways Department of DKI Jakarta

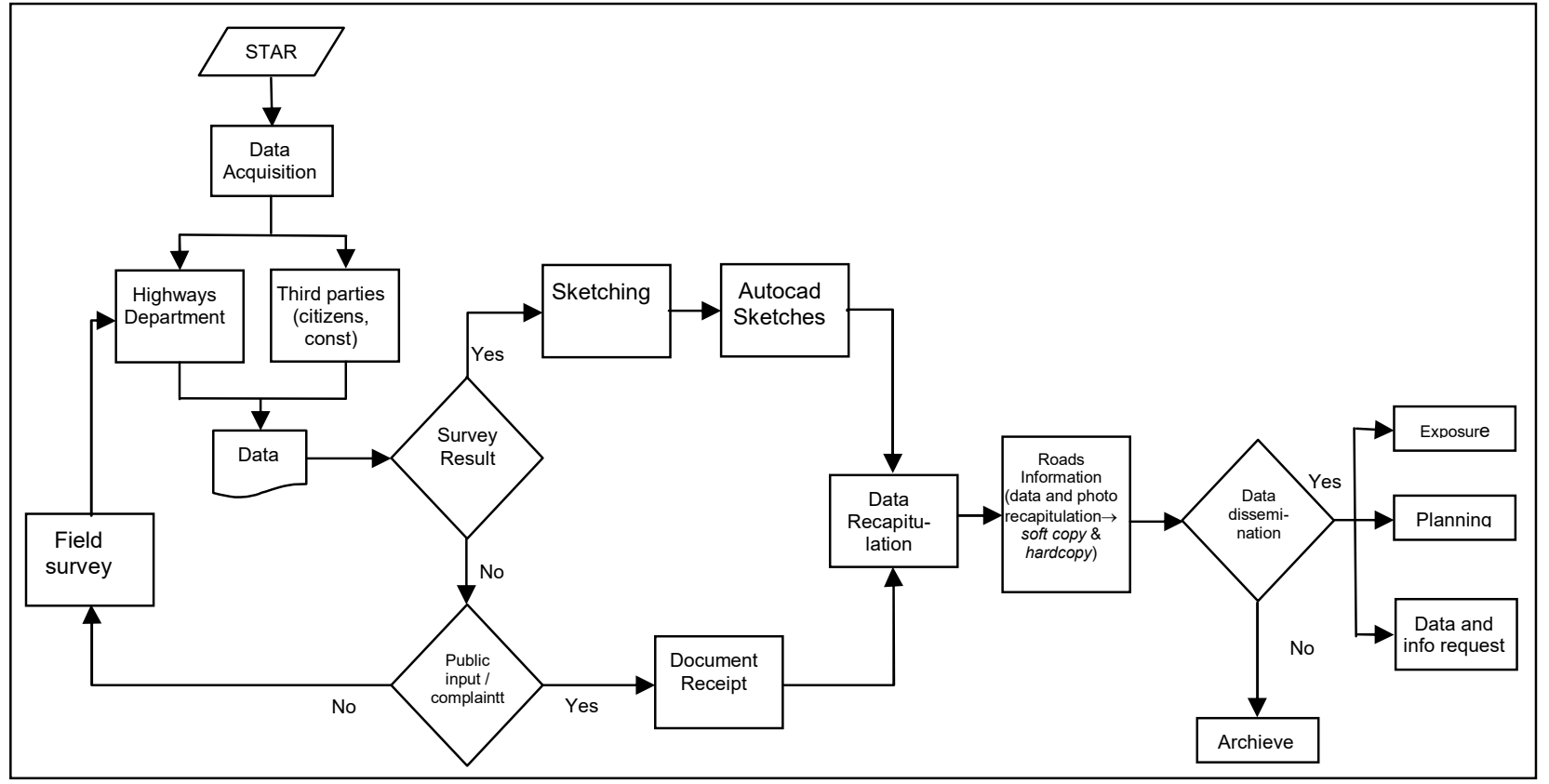

Figure 3 - Provision Path of Road Data and Information in Highways Department of DKI Jakarta

Interview on open data criteria of JSC Program with Mr. SA and interviews with Mr. Af and HP from Highways Department regarding the role of Highways Department of DKI Jakarta in JSC Program resulted in as follows:

(1) There is a difference of opinion about the openness of road data and information between JSC and Highways Department of DKI Jakarta. According to JSC, open data is standardized data and can be obtained free of charge through the open portal data of Jakarta Smart City (data.jakarta.go.id). Meanwhile, according to Highways Department of DKI Jakarta, the data has been open and accessed through official application.

(2) The data and information criteria owned by Highways Department of DKI Jakarta have not been able to comply with the laws and regulations as the legal basis for their implementation. This is due to abundant laws and regulations, causing confusion of public servants to take action and even innovation. In addition, the inability to utilize information and communication technology has not been followed up with collaborative steps with the parties who are able to solve this problem.

(3) In the end, there is awareness that the ways of data treatment by Highways Department of DKI Jakarta have been no longer sufficient for the development of the current demands of society. There should be better innovation and better use of ICT sophistication through JSC program.

(4) Innovation in the provision of road data and information by utilizing the sophistication of information and communication technology is preceded by the openness of data and public information Highways Department has through open data portal. It is hoped 
that there will be other parties, creators and innovators who are able to provide solutions for the problem of providing data and information on roads in Jakarta which is complete, accurate, up to date, easy to obtain, open and accessible to the administrators and the community.

\section{DISCUSSION OF RESULTS}

Based on the findings and studies conducted on the findings, it can be concluded that the provision of road data and information by Highways Department of DKI Jakarta in order to support the implementation of JSC Program has supporting and constraining factors. These factors are identified as follows:

(1) Supporting factors:

Having a command center. Command Center is under the control of the Planning and Budget Secretariat of Highways Department of DKI Jakarta. Although the task of the current command center is to monitor reports and public complaints through Qlue, Facebook, twitter, sms, and other social media, the functionality can be improved in road data and information management.

Having complaints channels. Qlue, Facebook, twitter, sms, hotlines and other complaints channels are very helpful for the duty of Highways Department of DKI Jakarta to get roads data, especially damaged roads.

Open data portal (https://data.jakarta.go.id) as data storage. The existence of open data portal as a storage of all development data held in the scope of DKI Jakarta Province, greatly facilitate Highways Department of DKI Jakarta to hold public information disclosure. Data and information that already exist and meet the criteria of open data portal can be directly uploaded. Stakeholders who need data and road information can directly download it.

(2) Inhibiting factors:

Too much regulation (overregulation). As mentioned previously, there are 6 (six) applicable rules underlying the provision of road data and information in Jakarta. These six regulations have a national scope, while Provincial Government of DKI Jakarta has not set specific rules on road data and information. Too much regulation creates confusion for the officials, causing less action and innovation in the implementation.

Having no guidelines on the implementation of road data and information management mechanism (SOP, MSS, operational guidelines, etc.). Guidelines regulate procedures to obtain data; process, present, and disseminate data that has become information; and incomplete activities of Highways Department of DKI Jakarta in providing road data and information. With the stipulation of road data and information management procedures, it is expected that good data criteria can be realized.

Having no own data unit. Data is an asset and needs management in the process, so the complete management should be accomplished as well. Establishment of individual data units that specialize in this function is needed to achieve better data and information management affecting better results. Provincial Government of DKI Jakarta also encourages the establishment of data units in each SKPD and conducts trainings on the human resources. Provincial Government also encourages the fulfillment of public information disclosure principle through JSC open portal data.

No optimal utilization of information and communication technology (ICT). ICT used in the provision of road data and information in Highways Department of DKI Jakarta has been limited to emails and social media to receive and disseminate data. This is considered inadequate for the development in the current era. ICTs can be further utilized by innovators through the applications they build.

Combining road data and information into Jakarta Smart City program is not too difficult, as the JSC information system has provided storage for data and development information throughout Jakarta through open data (https://data.jakarta.go.id). However, this merger is not without any obstacles. Four obstacles have been identified in the provision of road data and information in Highways Department of DKI Jakarta. 
Analysis of this data and information problem used Patton-Sawicki's policy analysis theory. The analysis is intended to provide policy recommendations that could encourage the active participation of Highways Department of DKI Jakarta in open data to realize the pillars of smart governance in the implementation of the JSC Program by addressing these four obstacles.

Verify, define, and detail the problems. This issue begins with too much legal basis (overregulated) of providing road data and information set by the government. Too many rules cause confusion and reluctance of the officials to carry out their duties. Other problems arise from that particular issue. The second problem is the absence of guideline on the provision of road data and information established in the scope of DKI Jakarta Province. So far, the guidelines have used legislative guidelines issued by the Ministry of Public Works. However, road databases are just one of the broader scopes of data and information. These guidelines are no longer sufficient to answer the society demands and the development urgency in this digital era. The third problem is no establishment of separate data units to perform road data and information management. The organizational structure of the road data and information provision is attached to other organizational structures within the scope of Highways Department of DKI Jakarta, so the officials often deal with the confusing conditions in determining the task priority to be completed first. The fourth problem is no optimal utilization of ICT. ICTs should also be utilized for more effective road data and information provision, by regarding the criteria set by the laws and regulations.

Based on the description of the above problems, it can be concluded that identified, detailed and verified problems are the inability of Highways Department of DKI Jakarta to provide good data and information in accordance with the criteria set out by the laws and regulations, causing the department unable to support the implementation of JSC program mainly in public information disclosure.

Establish evaluation criteria. Criteria used are effectiveness and efficiency because these criteria are also used in the activities of JSC Program based on Governor Regulation No. 181 of 2014. Efficiency in the scope of JSC means prioritizing the utilization of existing city resources, rather than getting them from outside. Therefore, it is necessary to recognize the present potential before making an action or innovation in the context of smart city. Effectiveness means the involvement of all stakeholders in a collaborative relationship in dealing with and seeking solutions for urban problems.

Identify alternative policy. The previous discussion has identified 4 (four) obstacles in fulfilling the road data and information provision in order to support the implementation of JSC Program. Each solution alternatives are identified against these four inhibiting factors.

Evaluate alternative policy. The aim is to provide relevant information on proposed policy alternatives. Since the policy has not yet been implemented, the ex-ante evaluation method is forecasting which takes into account the future conditions when a policy is enacted. Evaluation is done in accordance with the criteria set out in the second stage.

Display and distinguish among alternative policies. Patton \& Sawicki argues that choosing the best policy alternative is not enough by only considering the evaluation results from the fourth stage. There are other criteria to be considered, namely political viability, administrative operability, and legal feasibility criteria. Road data and information at Highways Department of DKI Jakarta acquire sufficient support to be accomplished. This is evident from the content of the six basic laws and regulations that instruct the government in accordance with its jurisdiction to achieve good road data and information and meet the complete, accurate, up-to-date, open, accessible criteria for the administrators and the public. In addition, Law No. 14 of 2008 on Transparency of Public Information and Governor Regulation of DKI Jakarta Province No. 181 of 2014 encourage better data development and information management, including road data and information.

Then political viability, administrative operability, and legal feasibility criteria are no longer taken into account in the stages of presentation and comparison of these policy alternatives because all policy alternatives receive equal political viability, administrative operability, and legal feasibility values. 
Table 2 - Comparison of policy alternatives

\begin{tabular}{|c|c|c|c|}
\hline Problems & Alternatives 1 & Alternatives 2 & Alternatives 3 \\
\hline $\begin{array}{c}\text { Too many laws and } \\
\text { regulations } \\
\text { (Overregulation) }\end{array}$ & $\begin{array}{c}\text { Status quo. } \\
\text { Ineffective and } \\
\text { inefficient. }\end{array}$ & $\begin{array}{c}\text { Road document as road } \\
\text { data. } \\
\text { Less effective and less } \\
\text { efficient }\end{array}$ & $\begin{array}{c}\text { Complete data and information } \\
\text { in accordance with six legal } \\
\text { basis. } \\
\text { Effective and efficient. }\end{array}$ \\
\hline Data unit & $\begin{array}{c}\text { Status quo. } \\
\text { Ineffective and } \\
\text { inefficient. }\end{array}$ & $\begin{array}{c}\text { New data unit. } \\
\text { Effective and less } \\
\text { efficient. }\end{array}$ & $\begin{array}{c}\text { Upgrade command center into } \\
\text { data units. } \\
\text { Effective and efficient. }\end{array}$ \\
\hline Guidelines (SOP) & $\begin{array}{c}\text { Status quo. } \\
\text { Ineffective and } \\
\text { inefficient. }\end{array}$ & $\begin{array}{c}\text { Guidelines (SOP) for road } \\
\text { documents. } \\
\text { Less effective and less } \\
\text { efficient. }\end{array}$ & $\begin{array}{c}\text { Guidance (SOP) for dand } \\
\text { road information in accordance } \\
\text { with six legal bases. } \\
\text { Effective and efficient. }\end{array}$ \\
\hline Technology & $\begin{array}{c}\text { Status quo (email and } \\
\text { social media). } \\
\text { Ineffective and } \\
\text { inefficient. }\end{array}$ & $\begin{array}{c}\text { Create an application / } \\
\text { portal independently. } \\
\text { Effective and less } \\
\text { efficient. }\end{array}$ & $\begin{array}{c}\text { Create an application / portal } \\
\text { through open data JSC. } \\
\text { Effective and efficient. }\end{array}$ \\
\hline
\end{tabular}

Table 2 shows the policy alternatives reviewed in the third and fourth stages. The results of the evaluation are compared by using the criteria set in the second stage in determining alternative policy criteria. Then, the recommended policy alternative is the third alternative because all these alternatives show the fulfillment of efficiency and effectiveness criteria.

Monitor policy implementation. The recommended policy implementation monitoring stage is conducted by measuring whether the impact of the policy brings maximum benefit to the stakeholders. Since policy recommendations have not been implemented, the method used is the measurement of policy implementation result projection towards the satisfaction of stakeholders in performing their activities. Stakeholders in this case are the government, private sector (business), and society. The result of policy implementation is the complete, accurate, up-to-date, open, easily obtained, and accessible road data and information by the administrators and the community.

The government uses these results as decision-making consideration, development planning, monitoring and evaluation of program and activity accomplishment, quality of public services improvement, and public information disclosure. Private sector requires appropriate road data and information for the decision-making process in running the business. For the public, excellent data and information in accordance with the criteria are used as a tool to monitor the development controlled by the government. It is also used as a basis for providing input to the government for better development. In addition, it can also be used to develop the creativity and innovation of public services. Subsequently, the data and information in accordance with the complete, accurate, up-to-date, open, easily obtained, and accessible criteria for the administrators and the public will be able to meet the needs of the society in performing these activities.

\section{CONCLUSION}

Road data and information provision within the scope of Highways Department of DKI Jakarta is one of the obligatory technical tasks as the road implementer in Indonesia's capital in order to support decision-making, planning, monitoring and evaluation functions. This study shows that technical functions in government agencies still require policy in the implementation. The policy is issued by officials who perform the activities as an implementation strategy. Stipulation of implementation strategy policy must be guided by above regulations which become the legal basis for the implementation. Therefore, it is important to take into account the flexibility of the policy implementer at the time of making the policy. 


\section{REFERENCES}

1. Nugroho, D, Riant, 2004, Kebijakan Publik, Formulasi Implementasi dan Evaluasi, Jakarta.Gramedia.

2. Nguyen, Lan. 2017. Open Data Master Plan of Toronto [Update Report]. Government of Toronto: Information \& Technology Division.

3. Kumorotomo,Wahyudi, 1996, Sistem Informasi Manajemen Dalam Organisasi Publik, Yogyakarta, Gajah Mada Press.

4. Anderson, James E. Public Policy Making. New York: Holt, Rinehart and Winston. 1984.

5. Sugiyono, 2014. Metode Penelitian Kuantitatif Kualitatif dan R \& D Bandung: Alfabeta

6. Wardiana, Wawan. 2002. Perkembangan Teknologi Informasi di Indonesia. Bandung

7. Winarno, Budi, 2012 .Kebijakan Publik Teori, Proses dan studi kasus, Jakarta: PT.Buku Seru.

8. http://smartcity.jakarta.go.id accessed on March 10, 2017 at 09.00 WIB 